\title{
Energy performance of soil management systems and crop rotation
}

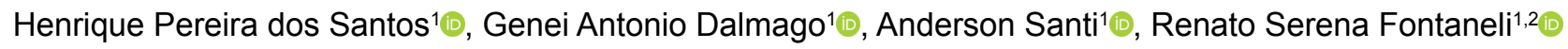 \\ 1'Embrapa Trigo, Passo Fundo-RS, Brasil. E-mail: henrique.santos@embrapa.br; genei.dalmago@embrapa.br; anderson.santi@embrapa.br; renato.fontaneli@embrapa.br \\ ${ }^{2}$ Universidade de Passo Fundo, Faculdade de Agronomia e Medicina Veterinária, Passo Fundo-RS, Brasil.
}

ABSTRACT: The objective of this study was to evaluate soil management and crop rotation systems. The treatments consisted of four types of soil management: 1) no-tillage, 2) minimum tillage, 3) conventional tillage with disc plows, and 4) conventional tillage with moldboard plows, and three crop rotation systems: system I - wheat/soybean; system II - wheat/soybean and vetch/ sorghum; and system III - wheat/soybean, vetch/sorghum and white oat/soybeans. An experimental design of randomized blocks with split-plots and three replicates was used. The main plot consisted of soil management systems, while the split-plots consisted of crop rotation systems. Maize and sorghum were the crops that showed the highest energy return in relation to the other studied species. No-tillage showed higher energy conversion and balance (12.31 and 45,011 $\mathrm{Mcal}^{\text {ha }}{ }^{-1}$ ) than minimum tillage (11.33 and $41,100 \mathrm{Mcal}^{-1}$ ha , conventional tillage using disk plow (9.94 and 34,142 $\left.\mathrm{Mcal}^{\text {ha }}{ }^{-1}\right)$ and conventional tillage using moldboard plow (10.21 and 35,170 $\mathrm{Mcal} \mathrm{ha}^{-1}$ ), respectively. Wheat in crop rotation had higher energy efficiency than the monoculture of this cereal.

Key words: energy balance; energy conversion; no-tillage system

\section{Desempenho energético de sistemas de manejo do solo e de rotação culturas}

RESUMO: O objetivo deste trabalho foi avaliar energeticamente sistemas de manejo de solo e de rotação de culturas. Os tratamentos consistiram em quatro tipos de manejo de solo: 1) plantio direto, 2) cultivo mínimo, 3) preparo convencional de solo com arado de discos e 4) preparo convencional de solo com arado de aivecas, e três sistemas de rotação de culturas: sistema I - trigo/soja; sistema II - trigo/soja e ervilhaca/sorgo; e sistema III - trigo/soja, ervilhaca/sorgo e aveia branca/soja. 0 delineamento experimental foi em blocos ao acaso, com parcelas subdivididas e três repetições. A parcela principal foi constituída pelos tipos de manejo de solo, e as sub-parcelas, pelos sistemas de rotação de culturas. O milho e o sorgo foram as culturas que mostraram maior retorno energético, em relação as demais espécies estudadas. $O$ sistema plantio direto mostrou maior conversão energética e balanço energético (12,31 e $\left.45.011 \mathrm{Mcal} \mathrm{ha}^{-1}\right)$ do que o cultivo mínimo (11,33 e $\left.41.100 \mathrm{Mcal} \mathrm{ha-1}^{-1}\right)$ e aos dos preparos convencionais de solo com arados de discos $\left(9,94\right.$ e $\left.34.1428 \mathrm{Mcal}^{-1} \mathrm{ha}^{-1}\right)$ e com arado de aivecas $(10,21$ e $35.170 \mathrm{Mcal}^{\text {ha-1 }}{ }^{-1}$ ), respectivamente. 0 trigo em rotação de cultura foi mais eficiente energeticamente do que a monocultura desse cereal.

Palavras-chave: balanço energético; conversão energética; plantio direto 


\section{Introduction}

The need in producing food for meeting the growing demand of the population has been presenting itself as a major problem. Arising in order to alleviate these problems, agricultural technological innovations aim at increasing yield, which in most cases demand a greater amount of energy, such as in systems of soil management, crop rotation, production of grain or with crop-livestock integration (Sá et al., 2013; Müller et al., 2017). This increase in the required energy is supplied by using fossil energy, considering a greater use of inputs such as fertilizers, pesticides, machinery and equipment (Santos et al., 2013). The main concern with exhausting this energy is due to the scarcity of energy resources, which is threatening the sustainability of grain production systems.

The conventional monoculture production system, based on agrochemistry, brings about a reduction in energy efficiency due to the small soil coverage (which induces losses by evaporation and erosion), associated with the great dependence on external inputs (mineral fertilizers and pesticides, both of a higher energy cost) (Teixeira et al., 2007; Souza et al., 2008; Andrea et al., 2014). In this sense, employing practices that reduce said problems can be the alternative in increasing the efficiency of the grain production systems, especially by employing crop rotations and management of species suitable for green manure, soil cover and fixation of carbon and nitrogen (Santos et al., 2011b; Ferreira et al., 2014; Costa et al., 2015).

In this process, for evaluating the energy balance, all used and produced inputs, which are later transformed into energy units, are identified and quantified. Thus, the energy flow analysis requires the unification of the product from different sources and energy converters, such as machines, human labor and fuel, in the same caloric unit (Soares et al., 2007; Santos et al., 2011a; Müller et al., 2017).

In the study by Santos et al. (2011b) about production systems with crop + livestock integration, the highest energy balance indexes occurred in the systems: wheat/soybean and vetch/maize; and wheat/soybean and pea/maize, in relation to the wheat/soybean and black oat/maize pasture systems; wheat/soybean and black oat/soybean pasture; wheat/soybean, vetch/soybean and dual-purpose triticale; and wheat/soybeans, dual-purpose white oats/soybeans and dual-purpose wheat/soybeans. Maize had the highest energy return, when compared to other grain-producing crops and winter pastures.

In another study, conducted by Santos et al. (2013), the wheat/soybean, white oat/soybean and vetch/maize systems, only for grain production; wheat/soybean, white oats/soybean and vetch/maize after perennial winter pastures; wheat/ soybean, white oats/soybean and vetch/maize after perennial summer pastures; and wheat/soybean, white oats/soybean and vetch/maize after lucerne were more efficient in energy conversion than the wheat/soybean, white oats/soybean and black oat + vetch pasture system. In this case, maize was the species that showed the highest energy return in relation to other grain-producing crops and winter pastures.
There are few studies available on conversion and energy balance that compare species and crops under different systems of soil management and crop rotation. According to Hetz \& Barrios (1997), the energy costs of systems with minimum cultivation and no-tillage were lower than the ones who employed conventional disc plowing. Santos et al. (2011a), when studying types of soil management and crop rotation, involving winter and summer crops, also found greater efficiency in energy consumption in the no-tillage. Among the studies with crop rotation systems, involving wheat under no-tillage, Santos et al. (2015b) stands out, with their results being superior for crop rotation when in comparison to the monoculture of this grass.

The present study aimed to evaluate the effect of soil management and crop rotation systems on the energy conversion and balance.

\section{Materials and Methods}

Data that served as basis in conducting this study came from grain yield, dry matter yield and its $\mathrm{N}$ amount, and the remaining straw amount from the plots species in the experiment of soil management systems and crop rotation involving wheat. This experiment was set up at Embrapa Trigo, in the municipality of Passo Fundo, RS, from 2010/2011 to $2017 / 2018$, in soil classified as a typical Dystrophic Red Latosol (Ultisol) (Weiler et al., 2017).

Treatments consisted of four soil management types: 1) notillage; 2) minimum tillage in winter, and no-tillage in summer; 3) conventional tillage with disc plow in winter, and no-tillage in summer; and 4) conventional tillage with moldboard plows in winter, and no-tillage (direct sowing) in summer. The three crop rotation systems were the following: system I - wheat/ soybean in monoculture; system II - wheat/soybean and vetch/ sorghum or maize, in 2017; and system III - wheat/soybean, vetch/sorghum or maize, in 2017 and white oat/soybean.

The experimental design was in randomized blocks, with split-plots and three replicates. The main plot $(4 \mathrm{~m}$ wide by $90 \mathrm{~m}$ long) was constituted by soil management systems, subplots ( $4 \mathrm{~m}$ wide by $10 \mathrm{~m}$ long) and by the crops that are part of the rotations.

The maintenance fertilization was performed according to the recommended for each crop (Soil Fertility and Chemistry Commission - RS/SC, 2016), also based on the soil analysis results. Soil samples were collected annually, after harvesting the summer crops.

Sowing time, weed control and phytosanitary treatments were all performed following the recommended for each crop. Harvesting was carried out with a special harvester for experimental plots, except in maize and sorghum crops, which were manually harvested. The yields of white oat, maize, soy, sorghum and wheat grains was corrected for $13 \%$ humidity.

Production matrices were used when quantifying the crop data, from which transformations were made to account for the energy available and consumed in these processes (Santos et al., 2013). For calculating the several indexes from the 
systems of soil management and crop rotation, grain and dry matter yield, remaining straw amount, $\mathrm{N}$ amount in dry matter and field operations, data and guidelines generated by Santos et al. (2013) were used. In the vetch case, yield was considered as the contribution based on the percentage of nitrogen and dry matter straw (Table 1 ). The data were transformed into Mcal (kcal x 1,000) (Santos et al., 2015a).

Available energy or energy revenue (Mcal ha-1) was considered as the transformation into energy of the grain yield, the amount of $\mathrm{N}$ in the dry matter and the remaining straw amount from the species. For consumed energy or cultural energy ( $\mathrm{Mcal} \mathrm{ha}^{-1}$ ), it was considered the estimated sum of the energy coefficients corresponding to the correctives, fertilizers, seeds, fungicides, herbicides and insecticides used in all types of soil management or crop rotation, as well as the energy consumed in operations (sowing, fertilization, pesticides application and harvestings). The energy conversion is result from the division of the available energy (Mcal ha

Table 1. Energy coefficients per unit of inputs, field operations, grain yield and dry matter used in soil management systems and crop rotations for wheat.

\begin{tabular}{|c|c|c|c|}
\hline Specification & Unit & Kcal/unit & Reference \\
\hline \multicolumn{4}{|l|}{ Consumed energy: } \\
\hline Seed-white oat & $\mathrm{kg}$ & 4,108 & Santos et al. (2013) \\
\hline - vetch & $\mathrm{kg}$ & 7,584 & Santos et al. (2013) \\
\hline - maize & $\mathrm{kg}$ & 24,806 & Santos et al. (2013) \\
\hline - soybean & $\mathrm{kg}$ & 7,584 & Santos et al. (2013) \\
\hline - sorghum & $\mathrm{kg}$ & 14,220 & Santos et al. (2013) \\
\hline - wheat & $\mathrm{kg}$ & 3,002 & Santos et al. (2013) \\
\hline Fertilizer - $\mathrm{N}$ & $\mathrm{kg}$ & 18,518 & Santos et al. (2013) \\
\hline$-P$ & $\mathrm{~kg}$ & 3,350 & Santos et al. (2013) \\
\hline$-\mathrm{K}$ & $\mathrm{kg}$ & 2,315 & Santos et al. (2013) \\
\hline Fungicide - azoxystrobin + benzovindiflupir & $\mathrm{L}$ & 64,910 & Santos et al. (2013) \\
\hline - azoxystrobin + Ciproconazole & $\mathrm{L}$ & 64,910 & Santos et al. (2013) \\
\hline - carboxine + tyrann & $\mathrm{kg}$ & 51,600 & Santos et al. (2013) \\
\hline - pyraclostrobin + metconazole & L & 64,910 & Santos et al. (2013) \\
\hline - pirasclostrobin + methyl thiophanate + fipronil & $\mathrm{kg}$ & 51,600 & Santos et al. (2013) \\
\hline - tebuconazole & $\mathrm{L}$ & 64,910 & Santos et al. (2013) \\
\hline - triadimenol & $\mathrm{kg}$ & 51,600 & Santos et al. (2013) \\
\hline - triflostrobin + protioconazole & $\mathrm{L}$ & 64,910 & Santos et al. (2013) \\
\hline - trifoxystrobin + tebuconazole & $\mathrm{L}$ & 64,910 & Santos et al. (2013) \\
\hline Herbicide - atrazine & $\mathrm{L}$ & 99,910 & Santos et al. (2013) \\
\hline - atrazine + simazine & 1 & 99,910 & Santos et al. (2013) \\
\hline - bentazon & I & 99,910 & Santos et al. (2013) \\
\hline - cletodim & $\mathrm{L}$ & 99,100 & Santos et al. (2013) \\
\hline - clodinafope-propargil & $\mathrm{L}$ & 99,100 & Santos et al. (2013) \\
\hline - glyphosate & $\mathrm{L}$ & 99,910 & Santos et al. (2013) \\
\hline - haloxifop-r-metallic & $\mathrm{L}$ & 99,100 & Santos et al. (2013) \\
\hline - iodosulfuron-methyl & $\mathrm{kg}$ & 62,770 & Santos et al. (2013) \\
\hline - metsulfuron-metil & $\mathrm{L}$ & 99,910 & Santos et al. (2013) \\
\hline - paraquat & I & 62,770 & Santos et al. (2013) \\
\hline - setoxydin & $\mathrm{L}$ & 99,910 & Santos et al. (2013) \\
\hline Insecticide - chlorpyrifos & $\mathrm{kg}$ & 74,300 & Santos et al. (2013) \\
\hline - diflubenzorom & L & 86,910 & Santos et al. (2013) \\
\hline - imidacloprid & $\mathrm{kg}$ & 74,300 & Santos et al. (2013) \\
\hline - lambda-cyhalothrin & L & 86,910 & Santos et al. (2013) \\
\hline - thiametoxan + lambda-cyhalothrin & $\mathrm{L}$ & 86,910 & Santos et al. (2013) \\
\hline - triflumurom & $\mathrm{L}$ & 86,910 & Santos et al. (2013) \\
\hline Plowing, harrowing and minimal cultivation & h/e.t. & 5,190 & Santos et al. (2013) \\
\hline Sowing and fertilization & h/e.t. & 6,994 & Santos et al. (2013) \\
\hline Cover or product application & h/e.t. & 2,356 & Santos et al. (2013) \\
\hline Mechanic harvest & $h / \mathrm{col}$. & 187,131 & Santos et al. (2013) \\
\hline \multicolumn{4}{|l|}{ Produced energy: } \\
\hline - white oat & $\mathrm{kg}$ & 4,155 & Santos et al. (2013) \\
\hline - vetch & $\mathrm{kg}$ & 2,319 & Santos et al. (2013) \\
\hline - maize & $\mathrm{kg}$ & 3,950 & Santos et al. (2013) \\
\hline - soybean & $\mathrm{kg}$ & 4,000 & Santos et al. (2013) \\
\hline - sorghum & $\mathrm{kg}$ & 3,783 & Santos et al. (2013) \\
\hline - wheat & $\mathrm{kg}$ & 3,691 & Santos et al. (2013) \\
\hline
\end{tabular}

h/e.t.: working hour with equipment and tractor; $h$ /col.: working hour with harvester. 
$\left.{ }^{1}\right)$ by the consumed energy ( $\mathrm{Mcal}^{\mathrm{ha}}{ }^{-1}$ ), in each type of soil management or crop rotation. The energy balance results from the difference between the energy available and consumed, in each type of soil management or crop rotation.

The statistical analysis consisted of the analysis of variance from the energy conversion and the energy balance, within each year (winter + summer) and the years joint mean, from the $2010 / 2011$ to $2017 / 2018$ harvests. In the analysis of variance, the energy available and consumed by the crops part of the types of soil management and crop rotation were all considered. In the joint analyzes, treatments were considered as a fixed effect, while the effect of the year was as random. The parameters under study were subjected to analysis of variance by using the SAS statistical program version 9.4 (SAS, 2017). Means of the types of soil management or crop rotation were evaluated by employing the Duncan test, at the level of $5 \%$ probability of error.

\section{Results and Discussion}

Means of the conversion and the energy balance, both annual and from $2010 / 2011$ to $2017 / 2018$, as well as the statistical comparisons, the dry matter yield, winter and summer crops, soil management and crops rotation systems, are all found in the Tables, from 2 to 7.

The analysis of variance of the conversion and the energy balance from the grouped years resulted in a significant effect of the years, the types of soil management and the crop rotations (Tables 2 to 7). Santos et al. (2011a) found similar results. Santos et al. (2011b; 2013), studying grain production systems with plantation + livestock integration, also obtained similar results of conversion and energy balance. The results presentation on energy conversion and energy balance is as it follows.

Concerning the isolated energy conversion of winter and summer crops from the soil management systems, there was a difference among the means for each year. During this study period, from the grain-producing and ground-covering crops, both in winter and in summer, maize and sorghum were more efficient in energy conversion when compared to white oat, vetch, soybeans and wheat (Table 2). Santos et al. (2011a, b; 2013), while studying production systems with plantation and livestock integration, emphasized the energy conversion of maize and sorghum as summer crops. White oat, vetch and soybeans crops had an intermediate position in terms of energy conversion values. On the other hand, wheat had the lowest energy conversion index. In the vetch case, for soil cover and green manure, there was a reduction in the input of fossil energy, especially that related to nitrogen fertilizers application. The research by Andrea et al. (2014) with energy flows in forage production systems, also partially confirms the energy efficiency of maize and sorghum, together with perennial pastures such as Panicum maximum and Tifton 85, in relation to black oat, ryegrass, barley and millet.

In the period from $2010 / 2011$ to $2017 / 2018$, there was a difference in five out of the eight studied years, in the annual energy conversion (winter + summer) and in the mean of the years in between the soil management systems (Table 3). In the $2012 / 2015$ agricultural harvest, the no-tillage system was superior for energy conversion, compared to conventional tillage with moldboard plows, and did not differ from conventional tillage with disc plows and minimum cultivation. In the agricultural crops of $2013 / 2014$ and $2014 / 2015$, the notillage system showed a higher energy conversion value than the other soil management types. In the agricultural harvest of 2016/2017, the no-tillage system, conventional tillage with moldboard plowing and minimum cultivation had a higher energy conversion index than the tillage with disc plow. In the 2017/2018 harvest, the no-tillage and the minimum cultivation system stood out regarding energy conversion values, in relation to conventional tillage systems. Hetz \& Melo (1997) report that the increase in the grain yield of crops (maize and wheat) and, consequently, the energy efficiency of the no-tillage system has increased over time. These same authors took into account the remaining straw of the studied species. Rising balance values indicate an increase in Mcal yield per Mcal invested, mainly due to increased grain yields, dry matter and nitrogen increases in the system.

In the joint mean of this studied period (from 2010/2011 to $2017 / 2018)$, the no-tillage system (12.31) showed a higher energy conversion than that of the minimum cultivation (11.33) and conventional tillage with disc plow (9.94) and with moldboard plow (10.21). Minimum cultivation ranked in an intermediate position for energy conversion rates. According

Table 2. Energy conversion (Mcal ha-1) of dry matter yield and of the winter and summer crops, over the years, in systems of soil management and crop rotation, from 2004/05 to 2009/10. Embrapa Trigo. Passo Fundo, RS.

\begin{tabular}{cccccccc}
\hline \multirow{2}{*}{ Harvest } & \multicolumn{7}{c}{ Crops } \\
\cline { 2 - 6 } & White oat & Vetch & Maize & Soybean & Sorghum & Wheat \\
\hline $2010 / 11$ & $10.71 \mathrm{C}$ & $15.90 \mathrm{~B}$ & - & $10.99 \mathrm{C}$ & $21.09 \mathrm{~A}$ & $10.32 \mathrm{C}$ & 13.30 \\
$2011 / 12$ & $11.12 \mathrm{~B}$ & $23.32 \mathrm{~A}$ & - & $4.40 \mathrm{D}$ & $8.97 \mathrm{C}$ & $11.97 \mathrm{~B}$ & 10.77 \\
$2012 / 13$ & $9.14 \mathrm{C}$ & $12.65 \mathrm{~B}$ & - & $9.30 \mathrm{C}$ & $15.49 \mathrm{~A}$ & $6.96 \mathrm{D}$ & 10.29 \\
$2013 / 14$ & $8.01 \mathrm{BC}$ & $6.30 \mathrm{C}$ & - & $12.21 \mathrm{~A}$ & $11.06 \mathrm{~A}$ & $8.70 \mathrm{~B}$ & 9.81 \\
$2014 / 15$ & $11.15 \mathrm{~B}$ & $18.21 \mathrm{~A}$ & - & $10.16 \mathrm{BC}$ & $8.96 \mathrm{C}$ & $6.63 \mathrm{D}$ & 10.50 \\
$2015 / 16$ & $12.62 \mathrm{AB}$ & $7.45 \mathrm{C}$ & - & $13.90 \mathrm{~A}$ & $13.86 \mathrm{~A}$ & $7.99 \mathrm{BC}$ & 11.23 \\
$2016 / 17$ & $11.75 \mathrm{C}$ & $5.73 \mathrm{D}$ & - & $15.26 \mathrm{~B}$ & $18.05 \mathrm{~A}$ & $11.74 \mathrm{C}$ & 12.96 \\
$2017 / 18$ & $10.90 \mathrm{C}$ & $2.51 \mathrm{E}$ & $14.16 \mathrm{~A}$ & $12.63 \mathrm{~B}$ & - & $7.92 \mathrm{D}$ & 9.88 \\
Mean & $10.68 \mathrm{~B}$ & $11.51 \mathrm{~B}$ & $14.15 \mathrm{~A}$ & $11.11 \mathrm{~B}$ & $13.93 \mathrm{~A}$ & $9.03 \mathrm{C}$ & 11.09 \\
\hline
\end{tabular}

Means followed by the same letter, horizontally, do not show significant differences, by Duncan test, at the level of $5 \%$ probability of error. 
Table 3. Effect of soil management types on energy conversion (Mcal ha-1 ${ }^{-1}$ ), in the harvests (winter + summer) from $2004 / 05$ to 2009/10. Embrapa Trigo. Passo Fundo, RS.

\begin{tabular}{|c|c|c|c|c|c|}
\hline \multirow{2}{*}{ Harvest } & \multicolumn{4}{|c|}{ Soil management systems } & \multirow{2}{*}{ Mean } \\
\hline & NT & CTD & CTM & MC & \\
\hline $2010 / 11$ & $14.24 \mathrm{~A}$ & $12.77 \mathrm{~A}$ & $13.30 \mathrm{~A}$ & $13.61 \mathrm{~A}$ & $13.48 \mathrm{a}$ \\
\hline $2011 / 12$ & $10.27 \mathrm{~A}$ & $10.11 \mathrm{~A}$ & $9.98 \mathrm{~A}$ & $9.85 \mathrm{~A}$ & $10.05 \mathrm{~b}$ \\
\hline $2013 / 14$ & $13.02 \mathrm{~A}$ & $8.16 \mathrm{C}$ & $8.16 \mathrm{C}$ & $10.28 \mathrm{~B}$ & $9.90 \mathrm{c}$ \\
\hline $2014 / 15$ & $11.45 \mathrm{~A}$ & $8.18 \mathrm{~B}$ & 8.59 B & $9.23 \mathrm{~B}$ & $9.36 \mathrm{c}$ \\
\hline $2017 / 18$ & $11.67 \mathrm{~A}$ & 9.38 B & $9.19 \mathrm{~B}$ & $10.92 \mathrm{~A}$ & $10.29 \mathrm{~b}$ \\
\hline Mean & $12.31 \mathrm{~A}$ & $9.94 \mathrm{C}$ & $10.21 \mathrm{C}$ & $11.33 \mathrm{~B}$ & 10.95 \\
\hline
\end{tabular}

NT: no-tillage; CTD: conventional tillage with disc plow in winter, and no-tillage (direct sowing) in summer; CTM: conventional tillage with moldboard plow in winter and no-tillage (direct sowing) in summer; and MC: minimum cultivation in winter and no-tillage (direct sowing) in summer. Means followed by the same uppercase letter horizontally and lowercase vertically, do not show significant differences by the Duncan test, at the level of $5 \%$ probability of error.

to Hetz \& Barrios (1997), the energy costs of soil management types with minimal cultivation and no-tillage were notably lower than the values of conventional tillage with disc plows. In the evaluation of the period from 2004/2015 to 2009/2010 (Santos et al., 2011a), the no-tillage system was superior, in terms of energy conversion rates, to the minimum cultivation and conventional tillage. The greater energy conversion in the no-tillage system, in relation to the conventional tillage management, can be partially explained by the reduction of the energy demands caused by the decreasing number of agricultural operations (Santos et al. 2011a; Townsend et al., 2016; Müller et al., 2017). Moreover, it should be considered that in all soil management systems in this study the remaining straw was also computed as produced energy, with it being higher in no-tillage than in the other studied managements.

In most of the studied years and in the analysis of the years joint mean, there were differences between the energy conversions of the different crop rotation systems (Table 4). The highest value in most harvests, with respect to energy conversion, manifested under crop rotation, in the systems II (wheat/soybean and vetch/sorghum or maize) and III (wheat/ soybean, white oat/soybean and vetch/sorghum or maize), compared to the system I (wheat/soybean monoculture). In the present study, maize and sorghum produced more straw than wheat. Therefore, crop rotation (systems II and III) was more efficient in energy conversion when compared to the wheat/soybean monoculture (system I). This efficiency is, in part, due to the amount of remaining maize or sorghum straw, added as produced energy, which in this study was greater than that of winter and soybean crops.

Regarding the energy conversion index, systems II (11.32) and III (11.34) were, in the analysis of the years joint means, superior to system I (9.04) (Table 4). This may be partly due to the cultivation of maize or sorghum, which showed greater energy conversion than soybean and the studied winter species. Hetz \& Melo (1997) report maize as an efficient crop $\left(127,218 \mathrm{MJ} \mathrm{ha}^{-1}\right)$ in converting energy, in comparison to wheat $\left(63,250 \mathrm{MJ} \mathrm{ha}^{-1}\right)$. Santos et al. (2011b), when working with production systems with crop + livestock integration from $2003 / 2004$ to $2008 / 2009$, found higher rates of energy conversion in the following systems: I: wheat/soybean and vetch/maize (49.52); and IV: wheat/soybean and pea/maize (52.12), compared to systems II: wheat/soybean and black oat/maize pasture (44.54); III: wheat/soybean and black oat/ soybean pasture (39.64); V: wheat/soybean, vetch/soybean and dual-purpose triticale (42.82); and VI: wheat/soybean, dual-purpose white oat/soybean and dual-purpose wheat/ soybean (40.71). According to the same authors, it is likely that the difference in favor of systems I and IV is related to the maize crop presence. It was preceded by winter green manure crops, which did not receive maintenance fertilizer, thus consuming less energy and providing more available energy to

Table 4. Effect of crop rotation systems on energy conversion (Mcal ha-1), in the harvests (winter + summer) from 2004/05 to 2009/10. Embrapa Trigo. Passo Fundo, RS.

\begin{tabular}{ccccc}
\hline \multirow{2}{*}{ Harvest } & \multicolumn{4}{c}{ Crop rotation systems } \\
\cline { 2 - 5 } & System I & System II & System III & Mean \\
\hline $2010 / 11$ & $9.29 \mathrm{~B}$ & $14.73 \mathrm{~A}$ & $14.04 \mathrm{~A}$ & $13.48 \mathrm{a}$ \\
$2011 / 12$ & $7.98 \mathrm{~B}$ & $10.85 \mathrm{~A}$ & $10.21 \mathrm{~A}$ & $10.05 \mathrm{~b}$ \\
$2012 / 13$ & $7.62 \mathrm{~B}$ & $11.03 \mathrm{~A}$ & $10.92 \mathrm{~A}$ & $10.41 \mathrm{~b}$ \\
$2013 / 14$ & $9.77 \mathrm{~A}$ & $9.22 \mathrm{~A}$ & $10.41 \mathrm{~A}$ & $9.90 \mathrm{C}$ \\
$2014 / 15$ & $7.24 \mathrm{~B}$ & $9.65 \mathrm{~A}$ & $9.88 \mathrm{~A}$ & $9.36 \mathrm{C}$ \\
$2015 / 16$ & $8.80 \mathrm{~A}$ & $12.31 \mathrm{~A}$ & $10.95 \mathrm{~A}$ & $11.04 \mathrm{~b}$ \\
$2016 / 17$ & $12.75 \mathrm{~A}$ & $12.78 \mathrm{~A}$ & $13.33 \mathrm{~A}$ & $13.05 \mathrm{a}$ \\
$2017 / 18$ & $8.85 \mathrm{~B}$ & $9.97 \mathrm{~A}$ & $10.98 \mathrm{~A}$ & $10.29 \mathrm{~b}$ \\
Mean & $9.04 \mathrm{~B}$ & $11.32 \mathrm{~A}$ & $11.34 \mathrm{~A}$ & 10.95 \\
\hline
\end{tabular}

System I: wheat/soybean; System II: wheat/soybean and vetch/sorghum; and System III: wheat/soybean, white oat/soybean and vetch/sorghum. Means followed by the same uppercase letter horizontally, and lowercase vertically, do not show significant differences by Duncan test, at the level of $5 \%$ probability of error. 
the systems and to the maize, grown without nitrogen cover fertilization. This made systems I and IV more energy efficient and had a direct impact on the systems energy conversion.

The evaluated types of soil management and crop rotation showed positive energy conversion rates (above 1.0), which means that all of them produced more energy than what they consumed (9.04 to 12.31). In this case, the studied types of soil management or crop rotation can be considered sustainable from an energy point of view.

In a study of production systems with crop + livestock integration, Santos et al. (2013) found that the wheat/soybean, white oat/soybean and vetch/maize systems, only for grain production (14.74); wheat/soybean, white oat/soybean and vetch/maize after perennial winter pasture (13.99); wheat/ soybean, white oat/soybean and vetch/maize after perennial summer pastures $(14,19)$; and wheat/soybean, white oat/ soybean and vetch/maize after lucerne (13.80) were more efficient in energy conversion than the wheat/soybean, white oat/soybean system and pasture of black oat + vetch (11.73). According to the same authors, the reason for this difference in favor of systems I, III, IV and V, in reaction to system II, may be related to their maintenance and top-dressing fertilization.

There were differences between the means of each year, of the isolated energy balance of the dry matter yield from winter and summer crops and of the soil management types.
In the period from 2004/2005 to $2009 / 2010$, sorghum was the most efficient crop regarding energy conversion when compared to the other studied crops (Table 5). Comparable results of energy yields were obtained in the maize crop by Hetz \& Melo (1997) and Santos et al. (2011a), who compared winter and summer species in types of soil management and crop rotation for several years in Concepción, Chile and Passo Fundo, RS, Brazil, respectively. However, all other studied species (white oat, vetch, wheat, soybean and sorghum), winter and summer alike, consumed less energy than what they took from the system.

When compared, the energy balance means from $2009 / 2010$ to $2017 / 2018$ showed differences between the soil management types, in six of the eight agricultural crops studied and in the years joint mean (Table 6). In the 2010/2011 and 2017/2018 agricultural harvests, the no-tillage system had a higher energy balance than the conventional tillage systems. In the agricultural harvests of 2012/2013, 2013/2014 and 2014/2015, the planting system was superior to the other studied systems regarding the energy balance index. However, in the 2016/2017 agricultural harvest, the no-tillage system, conventional tillage with moldboard plowing and minimum cultivation all showed higher energy balance values, in comparison to the conventional tillage system with disc plow.

Table 5. Energy balance (Mcal ha ${ }^{-1}$ ) of dry matter yield and winter and summer crops, in the years mean, in soil management types and crop rotation systems, from 2004/05 to 2009/10. Embrapa Trigo. Passo Fundo, RS.

\begin{tabular}{|c|c|c|c|c|c|c|c|}
\hline \multirow{3}{*}{ Harvest } & \multicolumn{6}{|c|}{ Crops } & \multirow{2}{*}{ Mean } \\
\hline & White oat & Vetch & Maize & Soybean & Sorghum & Wheat & \\
\hline & \multicolumn{7}{|c|}{ (Mcal ha-1) } \\
\hline $2010 / 11$ & $30.909 \mathrm{~A}$ & $9.683 \mathrm{D}$ & - & $15.165 \mathrm{C}$ & $25.463 \mathrm{~B}$ & $29.262 \mathrm{~A}$ & $20.803 b$ \\
\hline $2011 / 12$ & $25.600 \mathrm{~B}$ & $14.370 \mathrm{C}$ & - & $5.797 \mathrm{D}$ & $15.195 \mathrm{C}$ & $27.868 \mathrm{~A}$ & $15.960 \mathrm{c}$ \\
\hline $2012 / 13$ & 20.659 B & 8.791 D & - & $15.350 \mathrm{C}$ & $30.405 \mathrm{~A}$ & $14.489 \mathrm{C}$ & $16.993 \mathrm{c}$ \\
\hline $2013 / 14$ & $19.796 \mathrm{~A}$ & $3.305 \mathrm{~B}$ & - & $19.228 \mathrm{~A}$ & $21.230 \mathrm{~A}$ & $21.706 \mathrm{~A}$ & $17.574 b$ \\
\hline $2014 / 15$ & $25.098 \mathrm{~A}$ & $10.631 \mathrm{C}$ & - & $16.570 \mathrm{~B}$ & $17.100 \mathrm{~B}$ & 19.133 B & $17.020 \mathrm{~b}$ \\
\hline $2015 / 16$ & $34.426 \mathrm{~A}$ & $7.844 \mathrm{D}$ & - & $19.157 \mathrm{CD}$ & $32.182 \mathrm{AB}$ & 20.792 BC & $21.123 \mathrm{a}$ \\
\hline $2016 / 17$ & $32.903 \mathrm{~A}$ & $5.769 \mathrm{C}$ & - & 20.878 B & $34.499 \mathrm{~A}$ & $32.741 \mathrm{~A}$ & $24.597 \mathrm{a}$ \\
\hline $2017 / 18$ & 29.927 B & $2.012 \mathrm{D}$ & $43.020 \mathrm{~A}$ & $18.773 \mathrm{C}$ & - & $20.370 \mathrm{C}$ & $21.349 \mathrm{a}$ \\
\hline Mean & 27.415 B & $7.801 \mathrm{E}$ & $43.020 \mathrm{~A}$ & 16.365 D & $25.153 \mathrm{BC}$ & $23.295 \mathrm{C}$ & 19.428 \\
\hline
\end{tabular}

Means followed by the same uppercase letter horizontally and lowercase vertically, do not show significant differences by the Duncan test, at the level of $5 \%$ probability of error

Table 6. Effect of soil management systems on the energy balance (Mcal ha ${ }^{-1}$ ), in the harvests (winter + summer) from $2004 / 05$ to 2009/10. Embrapa Trigo. Passo Fundo, RS.

\begin{tabular}{|c|c|c|c|c|c|}
\hline \multirow{3}{*}{ Harvest } & \multicolumn{4}{|c|}{ Soil management systems } & \multirow{2}{*}{ Mean } \\
\hline & NT & CTD & CTM & MC & \\
\hline & \multicolumn{5}{|c|}{ (Mcal ha-1) } \\
\hline $2010 / 11$ & $45.559 \mathrm{~A}$ & $38.334 \mathrm{~B}$ & 39.745 B & $42.791 \mathrm{AB}$ & $41.607 \mathrm{~b}$ \\
\hline $2011 / 12$ & $33.647 \mathrm{~A}$ & $31.357 \mathrm{~A}$ & $30.840 \mathrm{~A}$ & $31.839 \mathrm{~A}$ & $31.921 \mathrm{c}$ \\
\hline $2012 / 13$ & $41.066 \mathrm{~A}$ & $31.062 \mathrm{BC}$ & $29.159 \mathrm{C}$ & 34.658 B & $33.986 \mathrm{c}$ \\
\hline $2013 / 14$ & $47.101 \mathrm{~A}$ & $27.851 \mathrm{C}$ & $28.050 \mathrm{C}$ & 37.594 B & $35.149 \mathrm{~b}$ \\
\hline $2014 / 15$ & $42.811 \mathrm{~A}$ & $28.999 \mathrm{C}$ & $30.467 \mathrm{BC}$ & 33.885 B & $34.040 \mathrm{c}$ \\
\hline $2015 / 16$ & $46.775 \mathrm{~A}$ & $35.545 \mathrm{~A}$ & $36.289 \mathrm{~A}$ & $50.378 \mathrm{~A}$ & $44.246 a$ \\
\hline $2016 / 17$ & $53.379 \mathrm{~A}$ & $42.164 \mathrm{~B}$ & $49.877 \mathrm{~A}$ & $51.361 \mathrm{~A}$ & $49.195 \mathrm{a}$ \\
\hline $2017 / 18$ & $49.746 \mathrm{~A}$ & $37.823 \mathrm{~B}$ & $36.933 \mathrm{~B}$ & $46.292 \mathrm{~A}$ & $42.698 a$ \\
\hline Mean & $45.011 \mathrm{~A}$ & $34.142 \mathrm{C}$ & $35.170 \mathrm{C}$ & $41.100 \mathrm{~B}$ & 38.855 \\
\hline
\end{tabular}

NT: no-tillage; CTD: conventional tillage with disc plow in winter, and no-tillage (direct sowing) in summer; CTM: conventional tillage with moldboard plow in winter and no-tillage (direct sowing) in summer; and MC: minimum cultivation in winter and no-tillage (direct sowing) in summer. Means followed by the same uppercase letter horizontally and lowercase vertically, do not show significant differences by the Duncan test, at the level of $5 \%$ probability of error. 
Table 7. Effect of crop rotation systems on energy balance (Mcal ha-1), in the harvests (winter + summer) from 2004/05 to 2009/10. Embrapa Trigo. Passo Fundo, RS.

\begin{tabular}{|c|c|c|c|c|}
\hline \multirow{2}{*}{ Harvest } & \multicolumn{3}{|c|}{ Crop rotation systems } & \multirow{2}{*}{ Mean } \\
\hline & System I & System II & System III & \\
\hline $2010 / 11$ & $38.615 \mathrm{~B}$ & $39.641 \mathrm{AB}$ & $43.916 \mathrm{~A}$ & $41.607 \mathrm{~b}$ \\
\hline $2011 / 12$ & $29.612 \mathrm{~A}$ & $32.196 \mathrm{~A}$ & $32.507 \mathrm{~A}$ & $31.921 \mathrm{C}$ \\
\hline $2013 / 14$ & $39.857 \mathrm{~A}$ & 29.791 B & $37.152 \mathrm{AB}$ & $35.149 \mathrm{~b}$ \\
\hline $2014 / 15$ & $32.549 \mathrm{~A}$ & $32.737 \mathrm{~A}$ & $35.406 \mathrm{~A}$ & $34.040 \mathrm{c}$ \\
\hline $2017 / 18$ & $35.802 \mathrm{~B}$ & $41.184 \mathrm{~A}$ & $46.007 \mathrm{~A}$ & $42.698 \mathrm{a}$ \\
\hline Mean & $36.582 \mathrm{~B}$ & $37.526 \mathrm{AB}$ & $40.500 \mathrm{~A}$ & 38.855 \\
\hline
\end{tabular}

System I: wheat/soybean; System II: wheat/soybean and vetch/sorghum; and System III: wheat/soybean, white oat/soybean and vetch/sorghum. Means followed by the same capital letter horizontally, and lowercase vertically, do not present significant differences, according to the Duncan test at the level of $5 \%$ probability of error.

The energy balance indexes from no-tillage system $(45,011$ Mcal ha-1), in the joint mean of the agricultural harvests (2010/2011 to $2017 / 2018$ ), were higher than the other soil management types of minimum cultivation: $41,100 \mathrm{Mcal}^{\text {ha-1, }}{ }^{-1}$ conventional tillage with disc plow: $34,142 \mathrm{Mcal} \mathrm{ha}^{-1}$ and with moldboard plow: 35,170 $\mathrm{Mcal}^{-1}$ ) (Table 6). The minimum cultivation index ranked between the other soil managements and the no-tillage system. In this study, the soil management type that consumed most energy (conventional tillage with disc plow and moldboard plow) obtained the lowest energy return. Santos et al. (2011a) previously found a similar result by using this same experiment, in the evaluation of the harvests from 2004/2005 to 2009/2010.

In most of the studied years and their joint mean, there were differences between the obtained energy balance in the different crop rotation systems evaluated (Table 7). In the 2010/2011 harvest, system III (wheat/soybean, white oat/soybean and vetch/sorghum or maize) showed a higher energy balance than system I (monoculture wheat/soybean); however, it did not differ from system II (wheat/soybean and vetch/sorghum or maize). In the 2012/2013 and 2017/2018 harvests, systems II and III were superior to system I regarding energy balance indexes. In the 2013/2014 and 2016/2017 harvests, system I showed a higher energy balance when compared to system II; however, it did not differ from system III. In the joint mean of the harvests (from 2010/2011 to $2017 / 2018)$, system III $\left(40,500 \mathrm{Mcal} \mathrm{ha}^{-1}\right)$ had a higher energy balance index when compared to system I (36,582 Mcal ha$\left.{ }^{1}\right)$, but it did not differ from system II $\left(37,526 \mathrm{Mcal} \mathrm{ha}^{-1}\right)$. This may be due, in part, to the sorghum crop, which was the most efficient species in harnessing the available energy.

In the study developed by Santos et al. (2011b) with production systems with crop + livestock integration, from $2003 / 2004$ to $2008 / 2009$, the following systems: I: wheat/ soybean and vetch/maize $\left(148,854 \mathrm{Mcal} \mathrm{ha}^{-1}\right)$; II: wheat/ soybean and black oat/maize pasture $\left(155,543 \mathrm{Mcal} \mathrm{ha}^{-1}\right)$; and IV: wheat/soybean and pea/maize $\left(159,487 \mathrm{Mcal} \mathrm{ha}^{-1}\right)$, all had higher energy balance indexes than the other systems; III: wheat/soybean and black oat/soybean pasture $(122,734$ Mcal ha-1); V: wheat/soybean, vetch/soybean and dualpurpose triticale $\left(120,808 \mathrm{Mcal}^{-1} \mathrm{ha}^{-1}\right)$; and VI: wheat/soybean, dual-purpose white oat/soybean and dual-purpose wheat/ soybean $\left(130,000 \mathrm{Mcal}^{\mathrm{ha}}{ }^{-1}\right)$. According to the same authors, the biggest difference in energy balance when compared to the others is, in part, due to the maize crop, the species with the highest energy return.

When working with production systems that had crop + livestock integration, Santos et al. (2013) found that the wheat/soybean, white oat/soybean and black oat + vetch pasture $\left(42,671 \mathrm{Mcal} \mathrm{ha}^{-1}\right)$ systems were superior, in terms of energy balance indexes, to the system of wheat/soybean, white oat/soybean and vetch/maize after lucerne $(39,596$ Mcal ha- $^{-1}$ ). The wheat/soybean, white oat/soybean and vetch/ maize systems, only for grain production $\left(42,160 \mathrm{Mcal} \mathrm{ha}^{-1}\right)$; wheat/soybean, white oat/soybean and vetch/maize after perennial winter pasture $\left(40,204 \mathrm{Mcal} \mathrm{ha}^{-1}\right)$; and wheat/ soybean, white oat/soybean and vetch/maize after perennial summer pastures $\left(40,688 \mathrm{Mcal} \mathrm{ha}^{-1}\right)$ were in an intermediate position for the energy balance values.

Ferreira et al. (2014) analyzed the energy balance during the production process of main cereals in Rio Grande do Sul, in three production units from Rio-grandense Rice Institute: 1) irrigated rice cultivation with production systems with crop + livestock integration, with soybean cropping under notillage system alternating with ryegrass pasture; 2 ) irrigated rice cultivation with crop-livestock integration, with soybean cropping under no-tillage system and ryegrass pasture; and 3) wheat and soybean cultivation under no-tillage system. The same authors found that soybean activity under notillage system with crop rotation attained the highest energy efficiency.

\section{Conclusions}

The highest rates of conversion and energy balance occurred in the no-tillage system, in comparison to the other soil management types.

The rotation systems of wheat/soybean and vetch/ sorghum and wheat/soybean, vetch/sorghum and white oat/ soybean are to be preferred since they are more efficient in energy conversion, in substitution to the wheat and soybean monoculture. 


\section{Literature Cited}

Andrea, M. C. S.; Tieppo, R. C.; Gimenez, L. M.; Povh, F. P.; Katsman, T.; Romanelli, T. L. Energy demand in agricultural biomass production in Parana state, Brazil. Agricultural Engineering International: CIGR Journal, n. special, p. 42-51, 2014. https:// cigrjournal.org/index.php/Ejounral/article/view/2916/1878. 19 Mar. 2019.

Costa, N. R.; Andreotti, M.; Lopes, K. S. M.; Yokobatake, K. L.; Ferreira, J. P.; Pariz, C. M.; Bonini, C. dos S. B.; Longhini, V.Z. Atributos do solo e acúmulo de carbono na integração lavoura-pecuária em sistema plantio direto. Revista Brasileira de Ciência do Solo, v. 39, n. 3, p. 852-863, 2015. https://doi.org/10.1590/01000683rbcs20140269.

Ferreira, F. de F.; Neumann, P.S.; Hoffmann, R. Análise da matriz energética e econômica das culturas de arroz, soja e trigo em sistemas de produção tecnificados no Rio Grande do Sul. Ciência Rural, v.44, n.2, p.380-385, 2014. https://doi.org/10.1590/ S0103-84782013005000157.

Hetz, E.J.; Barrios, A.I. Reducción del costo energético de labranza/ siembra utilizando sistemas conservacionistas en Chile. AgroCiencia, v.13, n.1, p.41-47, 1997.

Hetz, E.J.; Melo, L.A. Evaluación energética de un sistema de producción de maíz y trigo com cero labranza: el caso de Chequén, Concepcion, Chile. Agro-Ciencia, v.13, n.2, p.181-187, 1997.

Comissão de Química e Fertilidade do Solo - RS/SC. Manual de calagem e adubação para os estados do Rio Grande do Sul e de Santa Catarina. 11.ed. Porto Alegre: Sociedade Brasileira de Ciência do Solo; Núcleo Regional Sul; Comissão de Química e Fertilidade do Solo - RS/SC, 2016. 376 p.

Muller, J.; Levien, R.; Mazurana, M.; Alba, D.; Conte, O.; Zulpo, L. Energy balance in crop-farming system under soil management and cover crops. Revista Brasileira de Ciências Agrárias, v.12, n.3, p.348-353, 2017. https://doi.org/10.5039/agraria.v12i3a5463.

Sá, J. e M.; Urquiaga, S.; Jantalia, C.P.; Soares, L.H. de B.; Alves, B.J.; Boddey, R.M.; Marchão, R.L.; Vilela, L. Balanço energético da produção de grãos, carne e biocombustíveis em sistemas especializados e mistos. Pesquisa Agropecuária Brasileira, v.48, n.10. p.1.323-1.331, 2013. https://doi.org/10.1590/S0100-204X2013001000003.

Santos, H.P. dos.; Fontaneli, R.S.; Spera, S.T. Avaliação de sistemas de rotação de culturas na conversão e no balanço energético, nas décadas de 1980 a 2010. In: Santos, H.P. dos; Fontaneli, R.S.; Spera, S.T.; Pires, J.L.F.; Santi, A. (Eds.). Sistemas de produção para cereais de inverno: 30 anos de estudos. Brasília: Embrapa, 2015a. Cap. 7, p.223-361.
Santos, H.P. dos; Fontaneli, R.S.; Spera, S.T.; Dreon, G. Conversão e balanço energético de sistemas de produção com integração lavoura-pecuária, sob plantio direto. Revista Brasileira de Ciências Agrárias, v.8, n.1, p.1-7, 2013. https://doi.org/10.5039/ agraria.v8i1a1392.

Santos, H.P. dos; Fontaneli, R.S.; Spera, S.T.; Maldaner, G.L. Conversão e balanço de energia de sistemas de produção com integração lavoura-pecuária sob plantio direto. Pesquisa Agropecuária Brasileira, v.46, n.10, p.1193-1199, 2011b. https://doi. org/10.1590/S0100-204X2011001000011.

Santos, H.P. dos; Fontaneli, R.S.; Spera, S.T.; Pires, J.L.F.; Santi, A. (Eds.). Sistemas de produção para cereais de inverno: 30 anos de estudos. Brasília: Embrapa, 2015b. 316p.

Santos, H.P. dos; Spera, S.T.; Fontaneli, R.S.; Dreon, G. Avaliação de práticas culturais na conversão e no balanço energético. Revista Brasileira de Ciências Agrárias, v.6, n.4, p. 634-641, 2011 a. https://doi.org/10.5039/agraria.v6i4a1366.

SAS Institute. SAS system for microsoft windows version 9.4. Cary: SAS, 2017.

Soares, L.H. de B.; Muniz, L.C.; Figueiredo, R.S.; Alves, B.J.R.; Boddey, R.M.; Urquiaga, S.; Madari, B.E.; Machado, P.L.O. de A. Balanço energético de um sistema integrado lavoura-pecuária no cerrado. Seropédica: Embrapa Agrobiologia, 2007. 16p. (Embrapa Agrobiologia. Boletim de Pesquisa e Desenvolvimento, 26). http://ainfo.cnptia.embrapa.br/digital/bitstream/ CNPAB-2010/34870/1/bot026.pdf. 29 Mar. 2019.

Souza, J.L. de; Casali, V.W.D.; Santos, R.H.S.; Cecon, P.R. Balanço e análise da sustentabilidade energética na produção orgânica de hortaliças. Horticultura Brasileira, v.26, n.4, p.433-440, 2008. https://doi.org/10.1590/S0102-05362008000400003.

Teixeira, A.H. de C.; Bastiaanssen, W.G.M.; Ahmad, N.D.; Moura, M.S.B.; Bos, M.G. Analysis of energy fluxes and vegetationatmosphere parameters in irrigated and ecosystems of semi-arid Brazil. Journal of Hydrology, v.362, p.110-127, 2008. https://doi. org/10.1016/j.jhydrol.2008.08.011.

Townsend, T. J.; Ramsden, S. J.; Wilson, P. Analysing reduced tillage practices within a bio-economic modelling. Agricultural Systems, v. 146, n. 1, p. 91-102, 2016. https://doi.org/10.1016/j. agsy.2016.04.005.

Weiler, D.A.; Parton, W.; Santos, H.P. dos; Santi, A. Crop biomass, soil carbon, and nitrous oxide as affected by management and climate: a day center application in Brazil. Soil Science Society of America Journal, v. 81, n. 4, p. 945-955, 2017 https://doi. org/10.2136/sssaj2017.01.0024. 